\title{
Characteristics of Motivated L2 Class Groups: From Language Teachers' and Students' Perspectives
}

\author{
Lilian Ya-hui Chang ${ }^{1}$ \\ ${ }^{1}$ Department of Foreign Langauge Instruction, Wenzao Ursuline University of Languages, Taiwan \\ Correspondence: Lilian Ya-Hui Chang, Department of Foreign Langauge Instruction, Wenzao Ursuline \\ University of Languages, Taiwan. Tel: 886-7-342-6031-5227. E-mail: 90029@mail.wzu.edu.tw
}

Received: March 31, 2014 Accepted: May 2, 2014 Online Published: June 13, 2014

doi:10.5539/elt.v7n7p159 URL: http://dx.doi.org/10.5539/elt.v7n7p159

\begin{abstract}
In most learning situations, learners are learning with their peers, and the teacher is teaching to a class, not to an individual learner. As it is indisputable that learners conceptualize their learning as occurring in a group, it is logical to assume that the class group has some effect on learners' learning. Thus, it could be constructive to investigate the characteristics of a motivating classroom environment and how teachers can help cultivate a more comforting learning environment fostered by a motivating environment. This research focuses on exploring the characteristics of a motivating L2 classroom environment from both language teachers' and learners' perspectives. A questionnaire with both closed- and open-ended questions was distributed to approximately 100 college L2 learners studying at a private language college (from three English learning class groups). These class groups' English teachers were also interviewed to share their ideas of what comprised a motivating environment. Both the questionnaire and interview data suggest the importance of good interaction in a motivating L2 environment. The data also reveal the importance of teacher enthusiasm toward teaching, positive learning attitude in students, a strong cohesiveness group, and positive group norms.
\end{abstract}

Keywords: class groups, English language learning groups, L2 motivation, college students

\section{Introduction}

\subsection{Research Background}

Much L2 learning research centers on an individualistic perspective that, given that learning is essentially a personal process, seems logical. However, while learning may appear to be an individual endeavor, most learning situations, especially in schools and universities, occur in groups. Through social interaction with their peers, individual learners may become interdependent, and thus significantly affected by their peers. As Schmuck and Schmuck (2001) note:

The students of a class are more than a collection of individuals. They form a social system with peers in which they experience interdependence, interaction, and common goal striving (p. 40).

Ushioda (2003) also points out that it is routine in communicative classrooms for learners to exchange information frequently and share interests with peers. All these descriptions emphasize that the context of the class (learner) group may influence its individual members in many ways. Keen teachers have undoubtedly recognized the importance of the learner group in influencing the behavior of individual learners. Partly in response to teachers' concerns in this area, we have witnessed the publication of useful, practice-oriented books promoting favorable classroom dynamics and group dynamics (e.g., Dörnyei \& Murphey, 2003; Hadfield, 1992). In addition, there has been an increase in theoretical treatment of the group dynamics theory (e.g., Dörnyei \& Malderez, 1999; Ehrman \& Dörnyei, 1998; Schmuck \& Schmuck, 2001). Yet, surprisingly, there have been few empirical studies on group dynamics. This research study is an attempt to respond to this need by examining the characteristics of a motivating classroom environment in the context of group dynamics theory.

Finally, it is important to clarify that most current literature on groups in language classrooms focuses on small-group work (usually 3-5 people) for collaborative learning activities in the classrooms. However, when discussing group dynamics theory, Dörnyei and Malderez (1997, 1999) and Ehrman and Dörnyei (1998) clarify their use of the term "group" noting that they regard the whole language class as a group. This research will follow the same usage of the term "group," referring to the whole class as one group and investigating the 
characteristics of a motivated language class from both college language learners' and teachers' perspectives.

\subsection{Research Propose}

In summary, this study has the following key purposes:

1) To explore college L2 students' perceptions of the characteristics of a motivating classroom environment.

2) To explore college L2 teachers' perceptions of the characteristics of a motivating classroom environment.

3) To deconstruct the data revealing gaps between learner/teacher perceptions.

\section{Literature Review}

One possible aspect of class motivation that we can explore from the existing literature is group dynamics theory. In this section, some major components of group dynamics will be discussed in turn: group cohesiveness, group norms, group leadership style, and group size.

\subsection{Group Cohesiveness}

Cohesiveness or cohesion promotes group members' feeling of identification with their group because it "results from perceived similarity and then from mutual acceptance" (Ehrman \& Dörnyei, 1998, p. 136). In a cohesive group, group members have a strong connection with each other and mutually accept each other. Hence, they participate more in group activities, communicate more, and are motivated to do their best to ensure the group's success, which positively motivates individuals. Group cohesiveness seems to be an important group characteristic since group cohesiveness is central to the few research studies on group processes in language learning (e.g., Clément et al., 1994; Senior, 1997, 1999; Hinger, 2006). This supports Dörnyei and Murphey's (2003) argument that group cohesiveness is a vital characteristic of group life since it has received the most attention in social psychology and in education literature.

Many research studies have focused on how cohesiveness affects group performance and productivity. For example, Clément et al. (1994) has also found that group cohesiveness has a direct effect on group performance. Hinger's (2006) research concludes that a learner group develops more cohesiveness and works more effectively in a compact course, where members meet for longer hours over a shorter period of time. Studies by Chang (2010) also identified how group processes affect individual language learners' motivation.

\subsection{Group Norms}

Group norms or group rules, if accepted and respected by all group members, influence members to act in accordance with normally accepted group behavior. Ehrman and Dörnyei (1998) propose that the norms set by the teacher and the learners within the learning group affect group behavior the most. Although norms can be explicit and openly discussed in a group, many of them are implicit, and in their words, "unspoken, mutually agreed on, and usually unconscious in groups" (p. 131). Group norms promote an effective learning environment and enhance learner motivation in two ways: 1) when positive, they reinforce group members' desires and needs to perform well (Moreland \& Levine, 1992) and 2) they can enhance learners' motivation by establishing appropriate boundaries (Dörnyei \& Malderez, 1999). Group norms, by establishing appropriate boundaries, can enhance the motivation of a group member whose behavior violates them. Suppose a group of learners set up the norms (either explicitly or implicitly) such as the habit of submitting each assignment on time. If one member fails to submit an assignment on time, he or she might receive direct negative feedback from peers or indirectly get cold shouldered. This unpleasant experience might motivate that student to work harder to better conform to this group norm in the future. "We should not underestimate the power of the group: it may bring significant pressure to bear and it can sanction-directly or indirectly - those who fail to conform to what is considered acceptable" (Dörnyei \& Malderez, 1999, p. 161).

\subsection{Group Leadership Style}

Group leadership examines how group leaders, such as teachers, communicate their classroom decisions to the group members - does the teacher have a democratic, autocratic, or laissez-faire attitude toward learners? Democratic teachers allow learners to participate in decisions regarding the types of learning activities they are involved in. Autocratic teachers decide everything and rarely allow learners to participate in lesson planning. Laissez-faire teachers do very little in the classroom and allow students to do whatever they want (Ehrman \& Dörnyei, 1998). Dörnyei and Malderez (1999) claim that learner motivation is lowest in laissez-faire groups as learners simply feel lost attempting to cope without suitable guidance from the group leader. On the other hand, motivation is highest in democratic groups. Swezey et al. (1994) also point out that while autocratic groups might perform better, democratic groups are more satisfied within their group. This is further verified by Ehrman and Dörnyei (1998) who explain Lewin et al.'s study from 1939: While autocratic groups may be more 
productive than democratic groups, the quality of the work from democratic groups is usually better. In addition, democratic teachers, by their sharing of decisions with learners and promoting autonomy in the classrooms, generate greater interaction and promote cooperation among peers within the classroom. Several researchers (Ames, 1984; Dörnyei, 1997; Ushioda, 1996) have argued that a cooperative learning structure in the classroom, in which learners share responsibility and learn from each other, is more effective and powerful, particularly in enhancing learners' intrinsic motivation. Learners are more relaxed in a cooperative learning structure, and by working with others and sharing responsibilities, they have a more enjoyable learning experience. In short, all evidence demonstrates that democratic leadership promotes higher motivation, especially intrinsic motivation, which in turn sparks a greater desire to work productively.

\subsection{Group Size}

Large group size poses both advantages and disadvantages to learner motivation, but most literature suggests a large group has negative effects such as less satisfaction with group membership and less participation in group activities (Levine \& Moreland, 1990); more conflicts among the group members and more difficulty reaching a consensus (Moreland \& Levine, 1992); and less task involvement and lower morale in the group (Baron \& Kerr, 2003). It seems intuitive to assume that with so many disadvantages, members in a large group probably develop less motivation to accomplish their tasks. Nevertheless, large group size still has its merits. According to Morgan and Lassiter (1992), one positive feature of a large group could be increased creativity because a greater number of individuals contributing leads to a higher chance of more creative ideas being generated. Because of this additional creativity, more resources are available to help group members achieve their goals, and more people are available whom they can ask for help when they encounter difficulties. Thus, overall group effectiveness is enhanced. This increased group effectiveness might motivate individual group members. Ehrman and Dörnyei (1998) offer a similar opinion by noting that "with certain types of tasks (such as brainstorming)" (p. 74), more people in the group may benefit since different members can effectively offer a wider range of experiences, knowledge, and skills.

This section has looked at four important components of group dynamics theory: group cohesiveness, norms, leadership style, and size. The significance of this research comes from acknowledging the limitation of individual perspectives on L2 learning. By including the wider social context, such as classroom environment, we may be able to shed some light on our understanding of language learning experiences. A starting point for exploring class environment is to investigate, from L2 learners' and teachers' viewpoints, what the characteristics are of a motivating class environment. Are these characteristics examples of group cohesiveness? Or are they related to group size? Or are there any other factors that are not mentioned in the group dynamics theory? Only when we indentify these important characteristics, can we, as language teachers, attempt to help learners create a better class group environment, which in turn could lead to more effective learning.

\section{Method}

\subsection{Research Questions}

The following research questions guided this study:

1) From college students' perspective, what are the important characteristics of a motivated class group?

2) From college teachers' perspective, what are some important characteristics of a motivated class group?

3) Are there any gaps between students' and teachers' perceptions of a motivated class group?

\subsection{Research Instrument and Procedure}

This research explores college L2 students' and teachers' views on the features of a motivated class group. Therefore, it adopted a mixed method research design - collecting both quantitative and qualitative data. The data collection was divided into three phases:

In the first phase, a general exploratory questionnaire was distributed to a sample of target research participants (approximately $50 \mathrm{~L} 2$ students). Two general questions comprised this exploratory questionnaire:

1) Think of a language class group you had before that was really "good." What made that class group so special? Please describe it.

2) In your own opinion, what are some factors that constitute a good, motivated class group? Please write all the factors you can think of that are important.

The purpose of this exploratory questionnaire was to collect data that could be used to design a more suitable questionnaire. Based on the responses from the exploratory questionnaire, a more sophisticated questionnaire 
was designed that contain both open-ended questions and Likert scale questions.

The second phase of the data collection was to distribute the revised version of the questionnaire to L2 learners (approximately 120 students from three class groups) and their respective English teachers.

The third and final phase of data collection consisted of interviews with these teachers to explore their views on the features of motivated class groups. These interviews were conducted to compare their perspectives with those of their students.

\subsection{Research Participants}

The data were collected at a college in southern Taiwan from November 2010 to February 2011. This sample pool was a convenience sample since the researcher was working at this research site during the data collection period and had access to groups of students that suited the selection criteria of this research study. Research participants were students from various departments who took compulsory English classes. Participation of students from various departments was important to get an accurate range of perspectives. Hence, the questionnaires were distributed to the "36-credit-English classes" in which students from various departments took compulsory English lessons. Students were sorted into these classes according to their English proficiency, and over their four years of study, had to complete a total of 36 credits of English classes. English teachers from these class groups participated in this study through one-to-one interviews with the researcher.

\section{Results and Discussion}

\subsection{Students' Viewpoints-Questionnaire Findings}

A total of 118 valid questionnaires were received. The raw data were entered into SPSS for statistical analysis. To integrate the data from the three individual class groups for a general overview (for the full version of the statistics results please refer to appendix 1), the questionnaire findings revealed that students found the most important characteristics of a motivated class group were statements No. 7 (the teacher should not have a cavalier attitude and let students do whatever they want) and No. 5 (the teacher and the students should have good interaction in a motivated class group). Out of a possible score of 4.00 , both statements received mean scores higher than 3.60 (for statement No. 7, the mean score was 3.65, std. $=.632$; for statement No. 5 , the mean score was 3.64 , std. $=.515)$. In addition, they also strongly supported statements No. $22(\mathrm{mean}=3.58$, Std. $=.618$ ) - "there should not be more than 40 students in a motivated class," No. 6 (mean $=3.57$, Std. $=.592$ ) - "Students should learn English in a relaxing environment," and No. 18 (mean $=3.56$, Std. $=.711$ ) - "Students in a motivated class should not just care about their own learning."

On the other hand, the least important statements for the students were statement No. 3 - "the number of students should be less than 25 in a motivating class" (mean $=2.82$, Std. $=.802)$ and statement No. 15 (mean $=2.84$, Std. $=.861$ ) - "students should only speak English during the class" both were judged the least important. This indicates that small group size did not appear to be a priority for these students as long as they got along well. This also indicated that they placed relatively little importance on the common norm of speaking only English in an English class.

To sum up, the questionnaire data indicate that these student participants value the importance of teachers' teaching attitude and the relationship between the teachers and the students. In addition, they also believe that having high cohesiveness among the students and learning in a non-threntening environment vital. In contrast, the smaller class group and speaking only L2 (an examples of class norm) are regarded less important for them.

\subsection{Teachers' Viewpoints-Interview Findings}

Two main themes emerged from all three teachers' perspectives of a motivated class group: good interaction between teachers and students and students' positive attitude toward learning.

\section{Good interaction between teachers and students}

The three teachers all mentioned in their interviews that having good interaction between teachers and students was vital to them for a motivated class group:

Teacher A: I like the class groups that are responsive and provide you feedback. I don't enjoy teaching those who are very quiet. I they are really quiet, I have no idea what they are thinking of.

Teacher B: I like the freshman class group that I'm teaching right now. They are willing to answer my questions without me asking several times. They also actively share their opinions in class. That's really nice.

Teacher C: I think a good class group has most students that are willing to particicate in class activites or discussions. When I ask them questions, I get responses. When they have any questions, they will ask. 
From the excerpts, we can see that such interactions include students taking the initiative to answer teachers' questions, ask questions when they do not understand something, share their opinions in class discussions, and participate in class activities. On the other hand, a class group in which no one answers teachers' questions, shows a willingness to participate in class activities, and shares opinions is considered an unmotivated class group.

\section{Students' positive attitude toward learning}

In addition to good interaction, these teachers believe that students' positive attitude toward learning was also vital:

Teacher A: A good class groups should have students that are willing to learn and have positive learning attitude. For instance, they attend classes on time and do their homework assignments.

Teacher B: Students need to have positive learning attitude. They need to be motivated and interested in the subject.

Teacher C: I think that students should display their willingness to learn, to participate in class, and be motivated to do their homework. If many of them skip classes for no reason, I'll feel very frustrated.

These teachers expressed that students need to show their interest in learning by attending every class (no unexcused absence) and coming to class on time. Other features of a motivated class group cited by teachers are students' willingness to do homework and give teachers feedback on their learning progress. In other words, students need to show their interest in the subject and be willing to spend time to excel in class.

\subsection{Discussion and Suggestions}

In summary, the questionnaire findings revealed that students believe teacher attitude toward the class is crucial in a motivated class group. If the teachers do not manage the class well, the students in the class will be affected by the teachers' unenthusiastic attitude, and will thus generate less enthusiasm toward English learning. On the other hand, if the teacher helps the class set appropriate norms and cultivates positive interaction among students, a motivated class group will more likely to be formed. In addition, a strong sense of cohesiveness among the group members with a relaxing learning environment is also vital for a motivating class environment.

Teachers also believe that students' positive attitude toward learning is vital for a motivated class group. If the students show enthusiasm about their learning, are willing to participate in class activities, and complete assignments, then the class is motivated as a group. What is also important is having good in-class interaction between teachers and students - students willing to answer teachers' questions, participate in class activities, and share their opinions.

In integrating these two sets of data - questionnaire data from student participants and interview data from teacher participants - a common, vital factor in both was the importance of good classroom interaction. A method to achieve this is for teachers to adopt a democratic leadership style. As Dörnyei (1997) and Ushioda (1996) point out, democratic teachers engage in their decision-making with their learners, thus creating a more autonomous classroom learning environment. Through promoting cooperation among peers, greater interaction will also be generated. In addition, learners may be more relaxed in a cooperative learning structure, and hence feel more at ease while interacting with others in the classroom. This is consistent with the students' view that teachers should not adopt a laissez-faire leadership style in which they do very little in the classroom and allow students to do whatever they want (Ehrman \& Dörnyei, 1998). The students expected teachers to be in charge while guiding them by creating an autonomy-supportive learning environment where positive interaction occurs.

While both student participants and teacher participants agreed on the importance of having good interaction in a motivated class group, other aspects of a motivated class group differed between the teacher participants and student participants. Student participants seem to emphasize on group cohesiveness and the beliefs that group members should not care only about themselves and the class group should have a relaxing atmosphere. On the other hand, teacher participants seem to focus more on positive group norms - coming to class on time, completing homework assignments, and answering teachers' questions. This could be because group members in a class group see each other every day; hence, they are more aware of the level of cohesiveness, even though it is an elusive concept, which cannot be immediately perceived by an outsider. On the other hand, since teachers typically only teach a particular class group weekly (for a language class at a college level in Taiwan), it is harder for them to determine the class group's level of cohesiveness. Instead, observing behaviors exhibited in the classroom is an easier way for them to evaluate the level of motivation of the class group. 


\section{Conclusions}

This study explores the characteristics of a motivated L2 class group, from both students' and teachers' perspectives; 118 students participated in this research by completing a questionnaire, while three teachers participated through semi-structured interviews. Both questionnaire and interview data suggested the importance of having good interaction in a motivated L2 class group. The data also revealed the importance of teacher enthusiasm toward teaching, students' positive learning attitude, strong group cohesion, and positive group norms. In summary, the findings suggest that to foster these characteristics of a motivated class group, teachers should adopt a democratic leadership style - sharing their decision-making with their students, thus creating a more autonomous learning environment in which greater interaction will be generated. Thus, they enable their students to feel more at ease in a cooperative learning environment, and hence more motivated to interact with others in the classroom.

\section{References}

Ames, C. (1984). Competitive, cooperative, and individualistic goal structures: A cognitive-instructional analysis. In R. E. Ames, \& C. Ames (Eds.), Research on Motivation in Education (pp. 177-207). New Work: Academic Press.

Baron, R. S., \& Kerr, N. R. (2003). Group Process, Group Decision, and Group Action (2nd ed.). Buckingham: Open University Press.

Chang, L. Y. H. (2010). Group Processes and EFL Learners' Motivation: A Study of Group Dynamics in EFL Classrooms. TESOL Quarterly, 44(1), 129-154. http://dx.doi.org/10.5054/tq.2010.213780

Clément, R., Dörnyei, Z., \& Noels, K. A. (1994). Motivation, self-confidence and group cohesion in the foreign language classroom. Language Learning, 44, 417-448. http://dx.doi.org/10.1111/j.1467-1770.1994.tb01113.x

Dörnyei, Z. (1997). Psychological process in cooperative language learning: Group dynamics and motivation. The Modern Language Journal, 81(4), 482-493. http://dx.doi.org/10.2307/328891

Dörnyei, Z., \& Malderez, A. (1997). Group dynamics and foreign language teaching. System, 25(1), 65-81. http://dx.doi.org/10.1016/s0346-251x (96)00061-9

Dörnyei, Z., \& Malderez, A. (1999). The role of group dynamics in foreign language learning and teaching. In J. Arnold (Ed.), Affect in language learning (pp. 155-169). Cambridge: Cambridge University Press.

Dörnyei, Z., \& Murphey, T. (2003). Group dynamics in the language classroom. Cambridge: Cambridge University Press.

Ehrman, M. E., \& Dörnyei, Z. (1998). Interpersonal dynamics in second language education: The Visible and Invisible Classroom. CA: Sage, Thousand Oaks.

Hadfield, J. (1992). Classroom dynamics. Oxford: Oxford University Press.

Hinger, B. (2006). The distribution of instructional time and its effect on group cohesion in the foreign language classroom: A comparison of compact and standard format courses. System, 34(1), 97-118. http://dx.doi.org/10.1016/j.system.2005.08.003

Levine, J. M., \& Moreland, R. L. (1990). Progress in small group research. Annual Review of Psychology, 41, 585-634. http://dx.doi.org/10.1146/annurev.psych.41.1.585

Moreland, R. L., \& Levine, J. M. (1992). The composition of small groups. Advances in Group Processes, 9 , 237-280.

Morgan, B. B., \& Lassiter, D. L. J. (1992). Team composition and staffing. In R. W. Swezey, \& E. Salas (Eds.), Teams: Their Training and Performance (pp. 75-100). Norwood, NJ: Ablex.

Schmuck, R. A., \& Schmuck, P. A. (2001). Group processes in the classroom (8th ed.). Madison, WI: Brown and Benchmark.

Senior, R. (1997). Transforming language classes into bonded groups. ELT Journal, 51(1), 3-11. http://dx.doi.org/10.1093/elt/51.1.3

Swezey, R. W., Meltzer, A. L., \& Salas, E. (1994). Some issues involved in motivating teams. In H. F. J. O’Neil, \& M. Drillings (Eds.), Motivation: Theory and Research (pp. 141-169). Hillsdale, NH: Lawrence Erlbaum.

Ushioda, E. (1996). Learner autonomy 5: The role of motivation. Dublin: Authentik.

Ushioda, E. (2003). Motivation as a socially mediated process. In D. Little, J. Ridley, \& E. Ushioda (Eds.), 
Learner autonomy in the foreign language classroom: Learner, teacher, curriculum and assessment (pp. 90-102). Dublin: Authentik.

\section{Appendices}

Appendix A

Questionnaire (English version)

The Characteristics of a "Good" Language Class

First, thanks for sparing your time to accomplish this questionnaire. Your suggestions will be a great help for my research. This questionnaire aims to investigate your opinion toward a good language classroom. The data you provide is only for the research. It will not affect your grade. Thus, please feel at ease to complete this questionnaire.

Wenzao Unsuline College of Languages

Department of Foreign Language Instruction, Lilian Y.-H. Chang

Part A. Background Information
1) Grade
$\square 3^{\text {rd }}$ grade
$\square 2^{\text {nd }}$ grade
$1^{\text {st }}$ grade
2) Gender
Male
$\square$ Female
3) My English teacher is

Part B. Open-Ended Questions

In your opinion, what elements do you think a "good" language class should have? Please list any important elements that you think a "good" language class should have. Thank you.

Part C. Please Read Carefully about the Following Statements that You Think a Good Language Class Should Have and Circle Your Opinion from 1-4

$\begin{array}{llll}1 & 2 & 3 & 4 \\ \text { Strongly disagree } & \text { Somewhat disagree } & \text { Agree } & \text { Strongly agree }\end{array}$

\begin{tabular}{|c|c|c|c|}
\hline Statement & Your $\mathrm{O}$ & nior & \\
\hline $\begin{array}{l}\text { 1. In a good language class, the students should hand in their assignments and do the } \\
\text { presentations on time. }\end{array}$ & 1 & 3 & 4 \\
\hline $\begin{array}{l}\text { 2. In a good language class, the teacher should give students some chances to suggest } \\
\text { what they want to learn on class. }\end{array}$ & 1 & 3 & 4 \\
\hline $\begin{array}{l}\text { 3. In a good language class, the minimum amount of the students should be less than } 25 \\
\text { people. }\end{array}$ & 2 & 3 & 4 \\
\hline $\begin{array}{l}\text { 4. In a good language class, it is not important for the students to know each other very } \\
\text { well. }\end{array}$ & 2 & 3 & 4 \\
\hline In a good language class, the teacher should have good interaction with the students. 1 & 2 & 3 & 4 \\
\hline In a good language class, the students should learn English in a relaxing way. & 2 & 3 & 4 \\
\hline $\begin{array}{l}\text { 7. In a good language class, the teacher should not be so strict; he/she should let } \\
\text { students to do whatever they like during the class. }\end{array}$ & 2 & 3 & 4 \\
\hline $\begin{array}{l}\text { 8. In a good language class, the teacher should let students to participate in the decision } \\
\text { making about the class. }\end{array}$ & 2 & 3 & 4 \\
\hline $\begin{array}{l}\text { 9. In a good language class, the students should help their peers with the homework and } \\
\text { share their thoughts to each other. }\end{array}$ & 2 & 3 & 4 \\
\hline 10. In a good language class, the students should have a positive learning spirit. & 2 & 3 & 4 \\
\hline $\begin{array}{l}\text { 11. In a good language class, the teacher should give students time to participate in } \\
\text { group discussions often. }\end{array}$ & 2 & 3 & 4 \\
\hline
\end{tabular}


12. In a good language class, the students should have a good relationship with each $1 \quad 2 \quad 34$ other.

13. In a good language class, the teacher should adjust the teaching ways and the content $1 \quad 2 \quad 34$ according to the students' advice.

14. In a good language class, the students should have the same learning objectives. $\quad \begin{array}{llll}1 & 2 & 3 & 4\end{array}$

15. In a good language class, the students should only speak English during the class. $\quad \begin{array}{lllll}1 & 2 & 3 & 4\end{array}$

16. In a good language class, the amount of the students is not important. $\quad 1 \quad 2 \quad 34$

17. In a good language class, the students should be acquainted with each other and have $\begin{array}{llll}1 & 2 & 3\end{array}$ a good relationship.

18. In a good language class, the students should only care about themselves instead of $1 \quad 2 \quad 3 \quad 4$ others.

19. In a good language class, the students should be punctual. $\quad 1 \quad 2 \quad 34$

20. In a good language class, the teacher should know how to get students' attention. $\quad \begin{array}{ccccc}1 & 2 & 3 & 4\end{array}$

21. In a good language class, the students should concentrate on the class and participate ${ }_{1} 2 \quad 3 \quad 4$ in the activities.

22. In a good language class, the maximum amount of the students should not more than $1 \quad 2 \quad 34$ 40 people.

23. In a good language class, it should have a good order.

24. According to the statements above, in your opinion, which one do you think is the No. most important? (choose one only)

This is the end of the questionnaire, thanks for your participation.

Appendix B

Descriptive Statistics of the Questionnaire

Table 1. Descriptive statistics of the questionnaire (all three class groups)

\begin{tabular}{|c|c|c|c|c|c|}
\hline & $\mathrm{N}$ & Minimum & Maximum & Mean & Std. Deviation \\
\hline$\overline{\mathrm{Q} 3}$ & 118 & 1 & 4 & 2.82 & .802 \\
\hline Q15 & 117 & 1 & 4 & 2.84 & .861 \\
\hline Q11 & 118 & 1 & 4 & 3.03 & .727 \\
\hline Q19 & 117 & 2 & 4 & 3.19 & .730 \\
\hline Q14 & 118 & 1 & 4 & 3.21 & .738 \\
\hline Q16 & 117 & 1 & 4 & 3.22 & .811 \\
\hline Q17 & 118 & 1 & 4 & 3.25 & .703 \\
\hline Q8 & 118 & 2 & 4 & 3.28 & .583 \\
\hline Q13 & 118 & 2 & 4 & 3.31 & .650 \\
\hline Q23 & 117 & 2 & 4 & 3.34 & .672 \\
\hline Q4 & 117 & 1 & 4 & 3.36 & .942 \\
\hline Q9 & 118 & 2 & 4 & 3.41 & .573 \\
\hline Q21 & 118 & 2 & 4 & 3.46 & .579 \\
\hline Q1 & 117 & 2 & 4 & 3.50 & .567 \\
\hline Q12 & 115 & 2 & 4 & 3.51 & .598 \\
\hline Q20 & 118 & 2 & 4 & 3.52 & .566 \\
\hline Q2 & 118 & 2 & 4 & 3.52 & .566 \\
\hline Q10 & 118 & 2 & 4 & 3.55 & .533 \\
\hline Q18 & 118 & 1 & 4 & 3.56 & .711 \\
\hline
\end{tabular}




\begin{tabular}{llllll}
\hline Q6 & 117 & 1 & 4 & 3.57 & .592 \\
Q22 & 118 & 1 & 4 & 3.58 & .618 \\
Q5 & 118 & 2 & 4 & 3.64 & .515 \\
Q7 & 118 & 1 & 4 & 3.65 & .632 \\
\hline
\end{tabular}

Valid N (listwise) 110

\section{Copyrights}

Copyright for this article is retained by the author(s), with first publication rights granted to the journal.

This is an open-access article distributed under the terms and conditions of the Creative Commons Attribution license (http://creativecommons.org/licenses/by/3.0/). 